\title{
SINGLE IMPLANT PLACEMENT IN THE AESTHETIC AREA: \\ IMMEDIATE LOADING VERSUS TRADITIONAL DELAYED: \\ SURGICAL APPROACH AND 5 YEARS LONG TERM EVALUATION
}

Carolina Lenzi

Private practice, Bologna, Italy

\section{Background and Aim}

The immediate implant placement in a fresh socket after tooth extraction is considered a reliable therapeutic procedure and it presents the advantage of having a considerable amount of native bone. This technique also reduces the number of surgical procedures and the overall treatment time, obtaining the patient's approval and satisfaction. The anterior aesthetic area is considered critical to treat: in fact it is fundamental to obtain hard and soft tissue stability in order to obtain long term biological and aesthetic success.

Clinical studies showed that in several situations the technique reported here is also applicable in the aesthetic area and if exclusion criteria are respected, the results obtained can be predictable. However this concept is still controversial and some authors suggest delaying the placement and loading of the implant in the aesthetic area.

The aim of this study is to evaluate and compare 2 STUDY GROUPS (immediate placement and loading-and delayed) of 20 single implants 10 for each group placed into the aesthetic area made by the same operator. Are included in this study only from incisors to canine area in upper and lower jaw and evaluated each one after 60 MONTHS.

\section{DEALAYED}
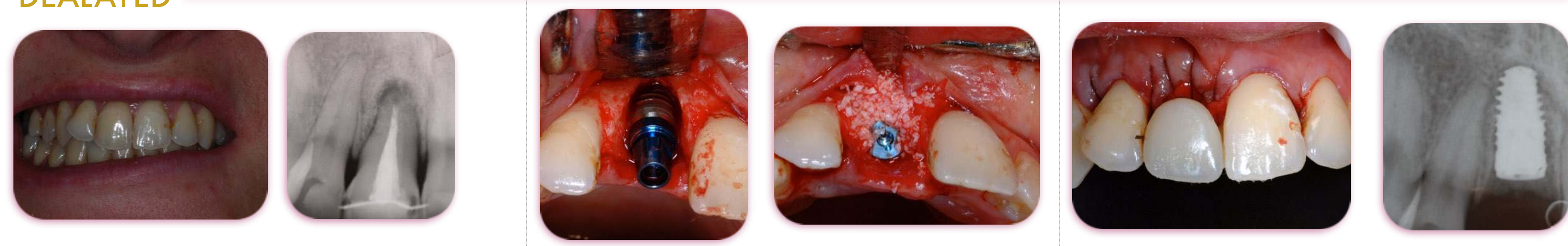

IMMEDIATE LOADING
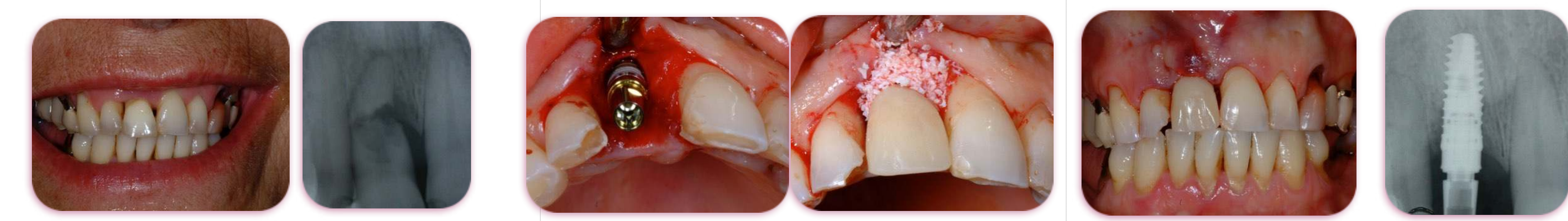

\section{DEALAYED}
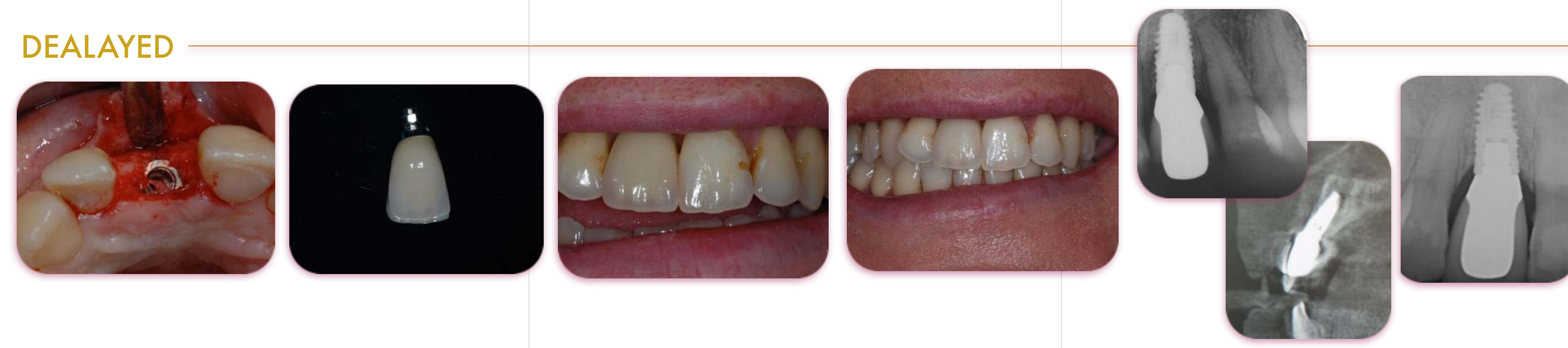

IMMEDIATE LOADING
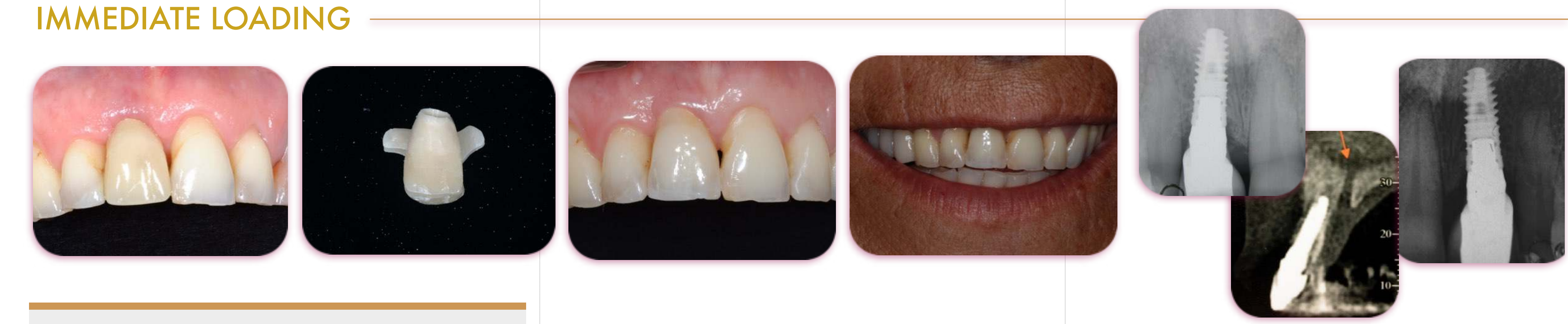

\section{References}

*Araujo MG, Sukekava F, Wennstrom JL Linde . Ridge alterations following implant placement in fresh extraction sockets: an experimental study in dog. J Clin Periodontol 2005;32:645-652 * Barone A, Rispoli L, Quaranta A, Covani U. Immediate restoration of single implants placet immediately after tooth extraction. J Periodontol. 2006:1 1; 1914-20

* Cornelini R, Cangini F, Covani U, Wilson TG Jr. Immediate restoration of implants placet into fresh extraction sockets for single-tooth replacement: a prospective clinical study. Int J Priodontics Restorative Dent. 2005:5; 439-47

* Palattella P, Torsello F, Cordaro L. Two-year prospective clinical comparison of immediate replacement vs. immediare restoration of single tooth in the esthetic zone. Clin Oral Implants Res. 2008:1 1; 1 1 148-53

* Crespi R, Cappare' P, Gherone E, Romanos GE. Immediate vs delayed loading of dental implants placet in fresh extraction sockets in the maxillary esthetic zone: a clinical comparative study. Int I Oral Maxillofac Implants. 2008: 4; 753-8

*De Rouck T, Collys K, Cosyn J. Single-tooth replacement in anterior maxilla by means of immediate implantation and provisionalization: a review. Int J Oral Maxillofac Implants. 2008: 5: 897-904 * Luongo G, Lenzi C, Raes F, Eccellemte T, Ortolani M, Mangano C. Immediate functional loading of single implants: 1 year interim report of a 5-year prospective multicentre study. EJOI 2014; 7(2):1-13 * Immediate Implant Placement and Provisionalization in the Esthetic Zone Using a Flapless or a Flap-lnvolving Approach: A Randomized Controlled Trial. Stoupel J, Lee CT, Glick J, Sanz-Miralles E, Chiuzan C, Papapanou PN. J Clin Periodontol. 2016 Aug 9. doi: 1

* Correlation between pre-operative buccal bone thickness and soft tissue changes around immediately placed and restored implants in the maxillary anterior region: A 2-year prospective study. Arora $\mathrm{H}$, Ivanovski S. Clin Oral Implants Res. 2016 Jul 29. 